\title{
New composites from waste: iron ore, pulp, lime, and concrete
}

\author{
Novos Compósitos à Partir De Resíduos: Minério de Ferro, Celulose, Cal e \\ Concreto
}

\author{
Cleber Luis Pedroso' \\ Vsévolod Mymrine " \\ Elizabete Yukiko Nakanishi"I \\ Daniela Evaniki Pedroso'v \\ Alfredo larozinski Netov \\ Rodrigo Eduardo Catai ${ }^{\mathrm{VI}}$
}

\begin{abstract}
This research aimed at the development of new composites for civil construction using only industrial waste, namely, iron ore tailings (IOT), pulp production waste (PPW), lime production waste (LPW), and concrete waste (CW). The characterization of raw materials was carried out through particle size, specific mass, hydrogen potential $(\mathrm{pH})$, loss on ignition (LOI) tests, and scanning electron microscopy (SEM); and, it was analyzed axial compression resistance and SEM in the developed composites. The specimens for the resistance test were molded, always using the same four types of residues in the mixture, with only water addition and no other type of binder. The residues proportions used were, in percentage, $10 \%$ to $40 \%$ of IOT and PPW, 25 to $30 \%$ of the LPW, and $15 \%$ to $25 \%$ of CW, distributed in 19 different compositions, that is, the proportions' variation of the residues in each specimen. The specimens were tested at the ages of $3,7,14,28,60,90,180,365$, and 720 days of cure. The results indicated a slight increase in resistance with increasing curing time, with emphasis on compositions 16 and 17, whose 28-day axial compression resistance reached $4.07 \mathrm{MPa}$ and $6.92 \mathrm{MPa}$, respectively. In these two compositions (16 and 17), the formation of new structures was observed in the materials due to the neutralization and dissolution of the surfaces, as the alkalinity gradually decreased over time, with the hydrogen potential $(\mathrm{pH})$ around 7.50 that, consequently caused the synthesis of new amorphous and crystalline formations. In this context, the studies allowed to conclude that the association of industrial residues has potential use as civil construction materials, for instance, in concrete artifacts, besides contributing to the reduction of finite natural resources extraction. It also provides a correct destination for the waste disposed of inappropriately, that constantly menaces the environment and the society that lives around it.
\end{abstract}

Keywords: Waste-based composites; Iron ore tailings; Concrete waste, Pulp waste, Lime production waste.

\section{Resumo}

Esta pesquisa propõe o desenvolvimento de novos compósitos para a construção civil, utilizando apenas rejeitos industriais, ou seja, os resíduos estudados são de minérios de ferro (RMF), resíduos da produção de celulose (RPCEL), resíduos da produção da cal (RPC), e resíduos de concreto (RC). Assim, inicialmente

\footnotetext{
'Universidade Tecnológica Federal do Paraná, Curitiba, PR, Brazil - cleber.ped@gmail.com.

" Universidade Tecnológica Federal do Paraná, Curitiba, PR, Brazil - seva6219@gmail.com.

II'Universidade Federal do Paraná, Curitiba, PR, Brazil - elizabete.nakanishi@ufpr.br.

IV Universidade Tecnológica Federal do Paraná, Curitiba, PR, Brazil-danievaniki@hotmail.com.

vUniversidade Tecnológica Federal do Paraná, Curitiba, PR, Brazil - alfredo.iarozinshi@gmaill.com.

VI Universidade Tecnológica Federal do Paraná, Curitiba, PR, Brazil - catai@ufpr.edu.br.
} 
realizaram-se os ensaios de caracterização dos resíduos: granulometria, massa específica, potencial hidrogeniônico $(\mathrm{pH})$, perda ao fogo (PF) e microscopia eletrônica de varredura (MEV), e nos compósitos confeccionados foram analisados a resistência à compressão axial e MEV. Foram moldados corpos de prova para o ensaio de resistência, utilizando-se sempre os 4 tipos de resíduos na composição da mistura e com acréscimo apenas de água, sem o uso de nenhum outro tipo de aglomerante. As proporções utilizadas em porcentagem dos resíduos RMF e RPCEL foram de $10 \%$ a $40 \%$, o RPC de 25 a $30 \%$ e o RC de $15 \%$ a $25 \%$, sendo distribuídos em 19 diferentes composições, ou seja, variação dos proporcionamentos das quantidades de resíduos em cada corpo de prova. As idades ensaiadas nos corpos de prova foram feitas com 3, 7, 14, 28,60, 90, 180, 365 e 720 dias de cura. Os resultados das 19 composições ensaiadas nos corpos de prova, indicaram leve aumento da resistência com o aumento do tempo de cura, no entanto as composições de número 16 e 17 destacaram-se em relações as outras, uma vez que as resistências à compressão axial aos 28 dias atingiram 4,07MPa e 6,92MPa, respectivamente. Nessas duas composições (16 e 17), observaram-se a formação de novas estruturas nos materiais em função da neutralização e dissolução das superfícies, pois gradativamente com o tempo baixaram a alcalinidade, tendo o potencial hidrogeniônico $(\mathrm{pH})$ cerca de 7,50 que, consequentemente ocasionaram a síntese de novas formações amorfas e cristalinas. Nesse sentido, os estudos permitiram concluir que os resíduos industriais associados, podem ser um potencial uso como materiais de construção civil, por exemplo em artefatos de concreto, além disso contribuem para diminuir a extração de recursos naturais finitos. Ainda propicia uma destinação correta aos resíduos depositados inadequadamente, oferecendo perigo constante ao meio ambiente e a sociedade que vive ao seu entorno.

Palavras-Chave: Compósitos à base de resíduos; Rejeitos de minério de ferro; Resíduos concreto, celulose e cal.

\section{Introduction}

The iron ore extraction is an essential economic activity in Brazil, corresponding to $87.70 \%$ of the exported primary goods and $4.0 \%$ of the Brazilian GDP (Gross Domestic Product). Brazil's iron ore reserves represent $11.90 \%$ of world reserves and are located in Minas Gerais, Mato Grosso do Sul, and Pará (DNPM, 2016). In these states, approximately 379 thousand tons of iron ore tailings (IOT) are generated daily, dumped in 672 tailings dams, 340 of which are located in the State of Minas Gerais (SNISB, 2018).

As generators of residues inherent to the manufacturing processes, there are yet the cellulose (PPW) and lime (LPW) plants, the latter with predominant use in civil construction. According to MONTE (2009), the pulp and paper mills also generate a wide variety of waste of organic and inorganic origin, becoming a primary environmental concern, causing the sector to seek new solutions for a correct final destination of this material. Solid residues are usual in kraft paper manufacturing processes, such as lime sludge, dregs, grits and sludge from water and wastewater treatment plants, as sulfide is added to the cooking process, which significantly accelerates delignification and, consequently, generates a more 
resistant final product, which is used in the packaging of sacks of cement, lime, and charcoal. For MANSKINEN, NURMESNIEMI, and PÖYKIÖ (2011), the kraft process factories built in the last ten years present solid residues generation between 40 to $70 \mathrm{~kg}$ dry/cellulose adt (adt = air dry ton), which corresponds to about 70 to $120 \mathrm{~kg}$ wet per ton of pulp produced. For example, the State of Paraná has approximately 52 factories producing pulp and paper; 5 are pulp factories, 6 are only paper factories, and 41 are integrated factories, that is, they produce high-yield pulp of cellulose and paper. The paper and pulp production in the State of Paraná represents $8.55 \%$ of the Brazilian ranking (BRACELPA, 2016).

Regarding lime production waste (LPW), GARCIA (2008) reported that the lime production residues originate from poorly burned limestone, i.e., when the combustion process occurs incompletely. These residues are generally marketed as by-products, consisting primarily of lime and non-limestone elements such as $\mathrm{Al}_{2} \mathrm{O}_{3}, \mathrm{SiO}_{2}, \mathrm{Fe}_{2} \mathrm{O}_{3}$, among others, in a total amount higher than 12\% (NBR 6453/2003). The perfect calcination depends on the operator's experience, the firing temperature, and the oven technology (OATES, 2008). However, most companies that work with lime are poorly structured and do not take into account the heat that would be needed inside rotary kilns, causing the generation of large amounts of waste (SALCUDEAN et. Al., 2004; CHIU and STROPKY, 2014).

Another potential waste generator is civil works, producing large volumes of concrete waste (CW). Assuming that concrete is made up of approximately $40-45 \%$ of cement consumption, and that aggregates added with water are 7 to 8 times the cement consumption volume contained in concrete, the enormous consumption of the material reported above becomes evident (SCRIVENER et al., 2018). According to Federal Law $\mathrm{n}^{\circ}$ 12,305 (National Policy on Solid Waste, Brazil, 2010), there must be links between the industry, production, services, and consumption sectors regarding the collection and correct reuse of solid wastes during their useful life and their proper final destination. In this regard, for FERREIRA and OLHERO (2002), the waste produced by a specific sector might often be considered as useful raw material for other industries, thus reducing the environmental impact. 
For all these reasons, this research considers the possibility of integrating iron ore tailings (IOT) and concrete waste (CW), with pulp (PPW) and lime (LPW) manufacturing processes wastes in the elaboration of new composites, and thus suggesting a new form of disposal for these wastes, turning them into raw materials for civil construction, imparting an enormous benefit to the environment with their reuse.

\section{Materials and Methods}

The compositions quantities (residues proportions) followed the historical traces of works published in international journals, being consistent with Mymrin et al.'s methodology that used glass waste (2020); mortar waste (2019); water treatment waste (2019); lime production waste (2019); sewage treatment plant waste (2018). Thus, 19 (nineteen) different mixture compositions of industrial wastes (IOT, PPW, LPW, CW) were pre-determined, adding only water for kneading, without the inclusion of any industrial binder such as Portland cement, plaster or lime. The proportion of each waste used to make the test specimens in percentage is shown in Table 1.

The selection of the residues under analysis was based on the principle that the binders react in an alkaline environment, so a residue with a high $\mathrm{pH}$ could provide a favorable condition for the lime production waste (LPW) to act with binder properties. Thus, the materials for carrying out the tests were only 4 (four) types of industrial waste, namely IOT, PPW, LPW, and CW (Figure 1).

Table 1 - Test specimens composition

\begin{tabular}{lcccc}
\hline Composition $\left(\mathbf{n}^{\circ}\right)$ & IOT (\%) & PPW (\%) & CW (\%) & LPW (\%) \\
\hline 1 & 30 & 30 & 25 & 15 \\
2 & 20 & 40 & 25 & 15 \\
3 & 40 & 20 & 25 & 15 \\
4 & 25 & 35 & 25 & 15 \\
5 & 35 & 25 & 25 & 15 \\
6 & 10 & 40 & 25 & 15 \\
7 & 40 & 10 & 25 & 15 \\
8 & 30 & 20 & 30 & 20
\end{tabular}




\begin{tabular}{lllll}
9 & 20 & 30 & 30 & 20 \\
10 & 25 & 25 & 30 & 20 \\
11 & 10 & 40 & 30 & 20 \\
12 & 40 & 10 & 30 & 20 \\
13 & 30 & 20 & 25 & 25 \\
14 & 20 & 30 & 25 & 25 \\
15 & 25 & 25 & 25 & 25 \\
16 & 10 & 40 & 25 & 25 \\
17 & 40 & 10 & 25 & 25 \\
18 & 35 & 15 & 25 & 25 \\
19 & 15 & 35 & 25 & 25 \\
\hline
\end{tabular}

The iron ore tailing (IOT) was collected after the Fundão dam burst in the Mariana region in Minas Gerais, Brazil. Concrete waste (CW), pulp production waste (PPW) and lime production waste (LPW) were collected from companies in the metropolitan region of Curitiba, in the state of Paraná, Brazil. Then, the four wastes gathering started in the concrete waste $(\mathrm{CW})$ processing company, from the processing of concrete blocks, shackles, concrete floors, slabs, pillars, and beams, whose maximum characteristic dimension found was $4.8 \mathrm{~mm}$. The pulp production waste (PPW) consisted of three residues (grits + dregs + lime mud), and the proportion of each in the mixture was defined by the historical average of generation in the industry. Thus, the percentages used (year 2019) were $34.33 \%$ (dregs), $37.12 \%$ (grits) and $28.53 \%$ (lime mud). The three wastes from the causticization process of cellulose production were collected in the places where they were discarded, namely dregs, grits, and lime mud. The lime production waste (LPW) was collected in the company's waste dump. Finally, the iron ore tailings (IOT) were collected, after the disaster of the Fundão dam rupture in Mariana/MG, in the path covered by the mud of the dam, that is, in the places where there were some residences.

Immediately after collecting the residues at the places of acquisition, they were packed in plastic bags and sealed in order to maintain their state of conservation and humidity as close as possible to the point of generation in the factories, finally, they were taken to the laboratory, where the tests were carried out. 
Weighing, drying, sieving, and delumping (lump breaking) methods were used for the wastes' characterization (granulometry, specific mass, hydrogen potential, and loss on ignition), mixing (proportioning) and homogenization, compaction, molding, and curing, for the analyses of axial compressive resistance and Scanning Electron Microscopy (SEM). The SEM method was carried out to verify the definition of the chemical and mineralogical compositions of the raw materials (wastes) and in the final compositions of the molded specimens.

Figure 1 - Waste Samples: (A) Iron Ore Tailing, (B) Pulp Production Waste, (C) Concrete Waste, and (D) Lime Production Waste

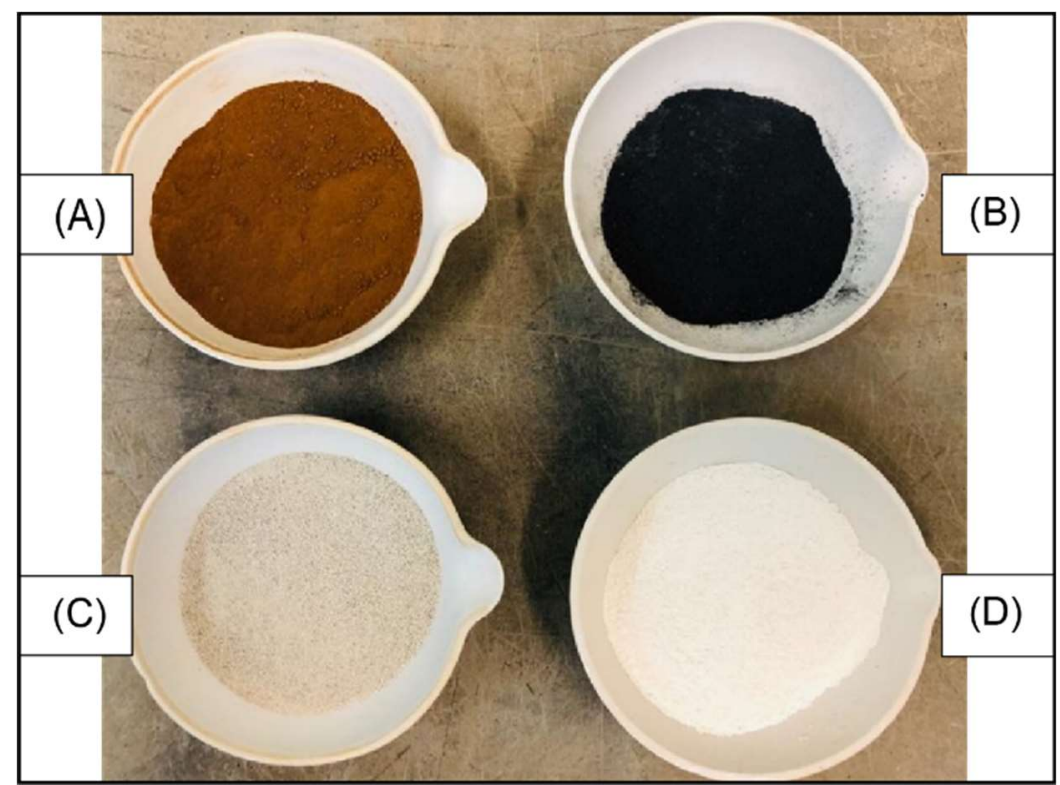

The testing methodology for determining the granulometric composition was in accordance with NBR NM 248 (ABNT, 2003) and classified according to NBR 7211 (ABNT, 2019), through a particle size distribution obtained through the sample sieving process. The specific mass is the relationship between the sample mass and its volume, excluding the permeable pores, and for its determination, it was used the NBR NM 52 (ABNT, 2009). To check the residues' $\mathrm{pH}$ (hydrogen potential), the $\mathrm{pH}$ was measured in two ways, the first using the universal indicator, which has different colors for each $\mathrm{pH}$ value. The second method was carried out in the laboratory, for which a peagameter was used, a device that measures the electrical conductivity of a solution and has a scale already graduated in $\mathrm{pH}$ values. The Scanning Electron Microscopy (SEM) and Energy-dispersive Spectroscopy (EDS) 
analyses were performed at UTFPR/campus Curitiba, using the ZEISS and OXFORD Instruments equipment, EVO MA15 and X-MAX models, with the software Smart SEM and INCA - Point \& ID, respectively, in which the morphological and atomic composition analyses of the specimens were performed. The sample preparation for the SEM test was carried out by fixing an amount of residue, approximately $1.5 \mathrm{~g}$, in support called stub and later metalized with a thin layer of $\mathrm{Au}$ (gold) to make them conductive, enabling the generation of high-resolution images of the material's surface. SEM method was used to study the morphological structures of the raw materials and the developed composites changes, both for the dry mix and for the specimens at 3, 7, 28 180, and 720 days.

The axial compressive resistance tests were carried out according to NBR 5739 (ABNT, 2007), using an EMiC universal press, model DL 30000, maximum capacity of $300 \mathrm{KN}$, with ball joint, which compressed the specimens to $2 \mathrm{~mm} / \mathrm{min}$ until the breaking limit of $30 \%$ is reached, providing the final test results. Using a Tesc software, the maximum force, in newton, and the tension, in megapascals (MPa), were observed, with which the samples' compressive resistance values were obtained. The composites developed with the residues studied here followed the premises of standard NBR 5738 (ABNT, 2003), in which the homogenization processes of the mixtures, molding, and curing of the test specimens stand out. For each composition (total of 19), 45 test specimens (TSs) were molded to determine the resistance, with 5 TSs being broken at each age $(3,7,14,28,60,90,180,365$, and 720 days). For the homogenization of residues according to the established compositions (Table 1), the necessary mass quantities were mixed by manually rummaging, checking the uniform coloring process, using a pestle and a mortar for this purpose, as the NBR 5738 standard (ABNT, 2003). For the TSs molding, a steel mold with $20 \mathrm{~mm}$ in diameter and $20 \mathrm{~mm}$ in height was used (Figure 2), in which $12.50 \mathrm{~g}$ of the composition was placed for later compaction, guaranteeing the uniformity of the mixture, according to NBR 5738 standard (ABNT, 2003). For compaction, the specimens, in the molds mentioned above, were compressed in a Bovenau manual hydraulic press, model P10ST, applying a force of 10MPa for 30 seconds. Forty-five (45) TSs were made for each of the 19 compositions in a cylindrical format with a $20 \mathrm{~mm}$ height and diameter. Finally, after the TSs compaction, they were stored in trays at 
room temperature and sheltered from the weather until the date of the respective tests, according to the standard NBR 5738 (ABNT, 2003).

Figure 2 - Mold and test specimens (TS) made with waste

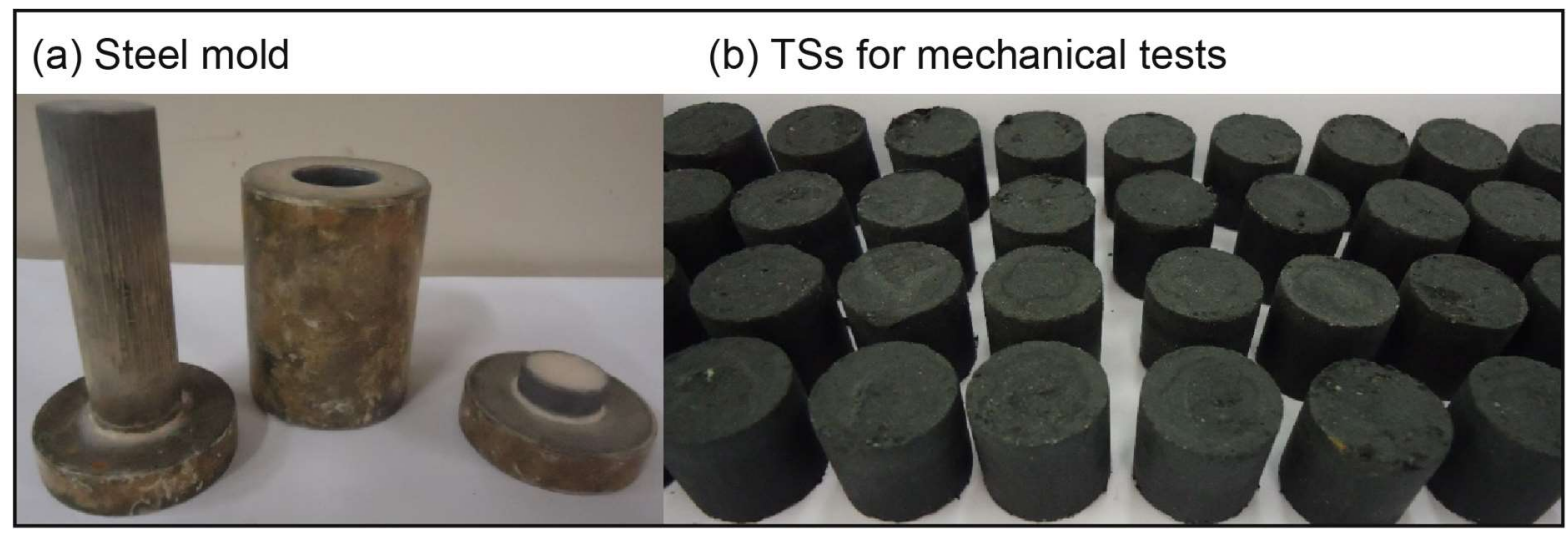

\section{Results and Discussion}

The results of the residue characterization tests, such as particle size, specific mass, hydrogen potential, loss on ignition, scanning electron microscopy (SEM), and the analysis of the compositions, are presented below.

\subsection{Particle Size of the Wastes}

Granulometry, graduation, or granulometric composition of an aggregate is the percentage distribution of its different grain sizes, considering the amount of material, by mass, retained in the sieves of the standard and intermediate series. The granulometric composition curve can be determined through this test, as shown in Figure 3, which contains the particle size distribution of the waste used. According to Sbrighi Neto (2005), a balanced granulometry has great importance in the concrete workability and economy, reducing the voids volume, and consequently, the spaces through which aggressive agents can penetrate the concrete.

Figure 3 - Particle Size Distribution of the Wastes. 


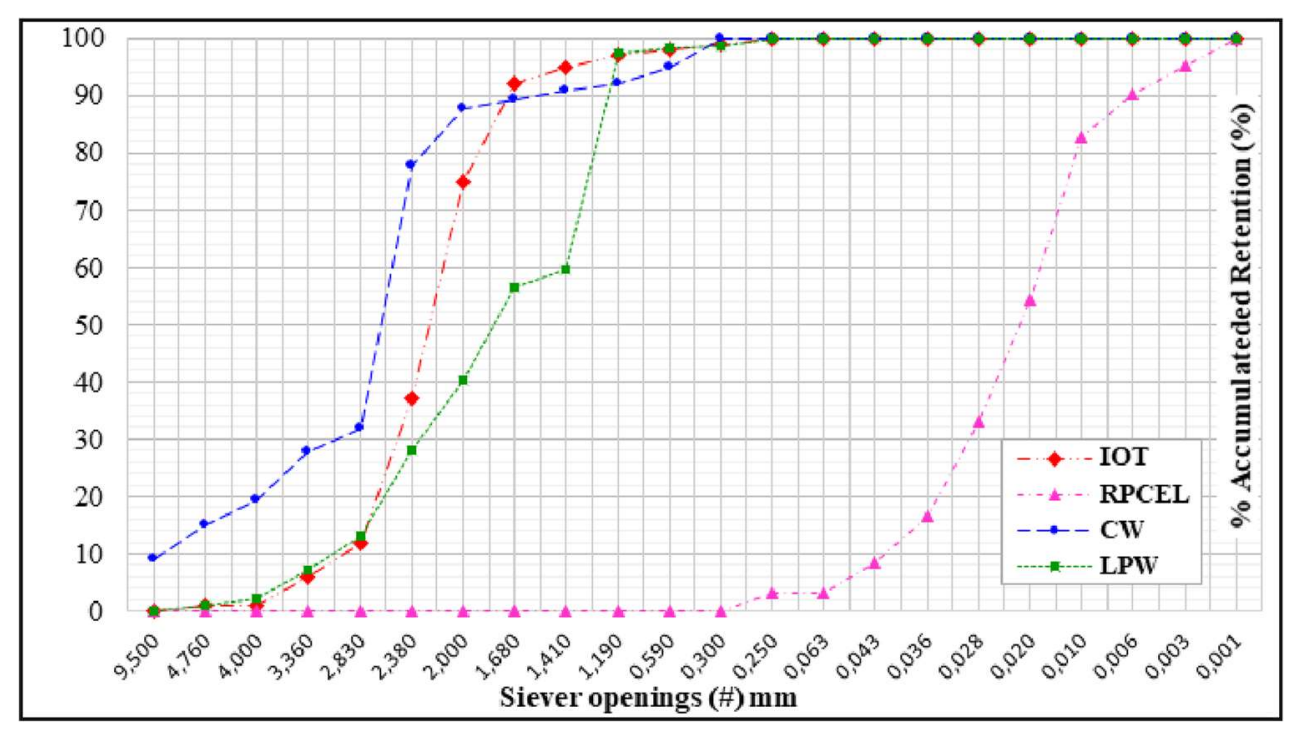

It is noticed that the grains from the iron ore tailings (IOT), lime production waste (LPW), and concrete waste (CW) are coarser than those from pulp production waste (PPW) due to the inherent manufacturing process. Nevertheless, all have grains with continuous distribution. According to HEWLETT (1998), if the granulometry is continuous (particles distributed uniformly in all dimensions from the smallest to the largest) and if the particles have a suitable shape, it is possible to obtain a compact and resistant concrete for minimum cement content, simultaneously reducing the segregation risk.

\subsection{Specific Mass, Hydrogen Potential and Loss on Ignition of the Wastes}

The specific mass property depends on the chemical structure, the molecular organization, and the packaging efficiency, and is defined as the material mass per volume unit, excluding the internal pores of the particles (voids). Thus, Table 2 indicates the values of the specific mass, hydrogen potential $(\mathrm{pH})$, and loss to fire (LOI) obtained for each residue under analysis. The hydrogen potential $(\mathrm{pH})$ determination was based on the principle that the binders react in an alkaline environment, so the selection of residues with alkaline $\mathrm{pH}$ could provide a favorable condition for them to act with binding properties. The Loss on Ignition (LOI), for its turn, determines the percentage of water mass and/or organic materials (might be a contaminant) lost or decomposed when the waste is subjected to a predetermined thermal heating cycle in a muffle furnace, as the Standard establishes

Table 2 - Specific Mass, Hydrogen Potential (pH) and Loss on Ignition (LOI) 


\begin{tabular}{lcccc}
\hline Property & IOT & PPW & LPW & CW \\
\hline Specific Mass $\left(\mathrm{g} / \mathrm{cm}^{3}\right)$ & 3,28 & 1,45 & 1,25 & 2,28 \\
Hydrogen Potential & 10,21 & 11,62 & 11,00 & 10,34 \\
Loss on Ignition (\%) & 3,08 & 41,32 & 16,20 & 10,60 \\
\hline
\end{tabular}

According to ANTT (2018), the grain density of iron ore tailings is conditioned to the iron content present in them. The iron particles have a specific mass of grains around 5.25 $\mathrm{kg} / \mathrm{dm}^{3}$, while quartz grains are characterized by having a specific mass around $2.65 \mathrm{~kg} / \mathrm{dm}^{3}$. It further states that iron ore tailings, which are basically composed of quartz and hematite particles, tend to have a range of variation in grain density between these two extremes. Its variation can be significant, even from low oscillations related to the iron content presented. In this context, it is observed that the IOT specific mass value $\left(3.28 \mathrm{Kg} / \mathrm{dm}^{3}\right)$ is in agreement with the literature since the grains are directly linked to the content of more dense minerals present in the tailings, closely related to the remaining fractions of iron oxide and other dense minerals in the manufacturing process, as well as related to the location where these tailings were collected, where contamination by other materials present at the time of collection may have occurred. In IOT's case, it is noteworthy that it was collected in the vicinity of the Vale Company dam burst, in the city of Mariana in Minas Gerais.

LEBEIS (2003) found a value of the specific mass of paper production waste for use in a mortar of $1.51 \mathrm{Kg} / \mathrm{dm}^{3}$, close to the value found in the present work of $1.45 \mathrm{Kg} / \mathrm{dm}^{3}$. This outcome is because the material used (paper production waste) has a lower density than traditional materials, such as natural aggregates. The specific mass value of the concrete waste (CW) was $2.28 \mathrm{~kg} / \mathrm{dm}^{3}$, also in line with the literature, since either the specific mass or the unit has lower densities in the waste than in natural aggregates. As an illustration, HANSEN (1992) reported specific mass values of aggregates from concrete ranging from $2.12 \mathrm{~kg} / \mathrm{dm}^{3}$ to $2.70 \mathrm{~kg} / \mathrm{dm}^{3}$, and specific mass values resulting only from the remains of concrete's oldish mortar with different a/c ratios (water/cement) around 2.00 $\mathrm{kg} / \mathrm{dm}^{3}$. Therefore, he concluded that the specific mass value is generally lower than that of 
natural aggregates due to the oldish mortar adhered to the particles of the recycled concrete aggregate.

The results obtained in the hydrogen potential analysis, where all residues presented $\mathrm{pH}$ above 10.0, can stimulate the formation of binders in all the compositions.

It is noted (Table 2) that the IOT (iron ore tailings) showed the lowest loss on ignition value (LOI), 3.08, compared to other residues. The research carried out by BEZERRA (2017) presented several values of loss on ignition that were studied by different authors, and that used iron ore tailings from the iron quadrilateral in Minas Gerais. The reported values were $3.91,0.94,9.37,3.61$, and 7.80 , i.e., much lower values than the other residues studied in this research. This finding suggests that the residue had practically non-volatile or insoluble solid parts at high temperatures. In comparison with the loss on ignition of the pulp production waste (PPW) of 41.32, this is much higher, characterizing the presence of organic materials inherent to the raw material used in the production process, which are contained in this residue. The values of the other two residues were between those obtained for IOT and PPW.

\subsection{Scanning Electron Microscopy of the Wastes}

Figure 4 shows images of the waste amplified 5,000 times. Analyzing Figure 4 items $(A, B, C$, and $D)$, it is observed that Figure $4(A)$ shows particles of varying dimensions and sizes that do not have connections between the grains and present voids, denoting a granular residue. In the research by MAGALHÃES (2018), compact particles without lamellar structures were verified, which may indicate a low specific surface area. The presence of very fine material adhered to the larger particles was also observed.

Figure 4 - Wastes' Morphological Structure - Amplification 5.000x 

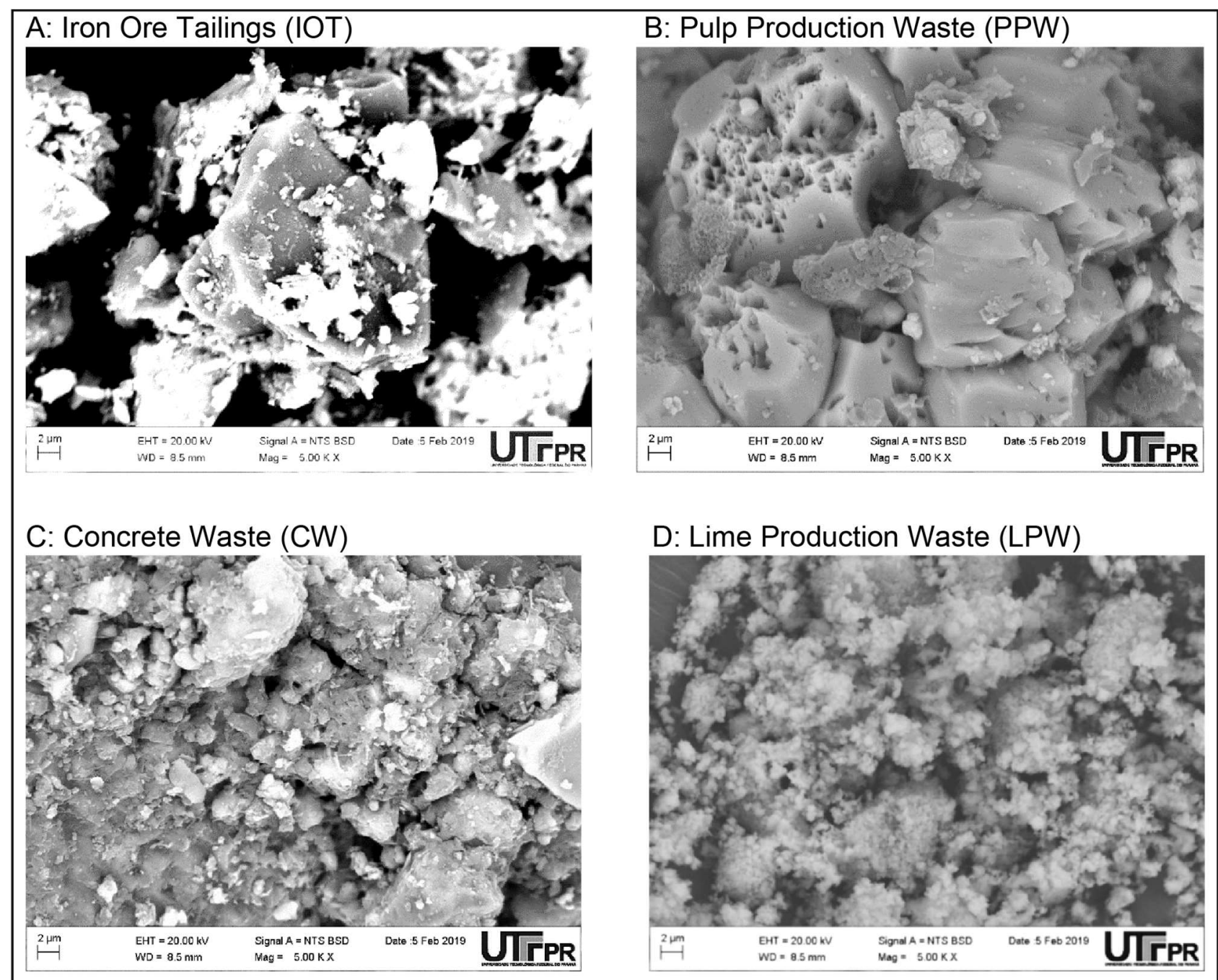

Figure 4 (B) shows grains with broken (fractured) particles, with smooth and loose surfaces (with no connection between them), with the detachment of smaller particles. This finding is due to the Kraft manufacturing process, obtaining caustification rejects such as dregs and grits. Figure 4 (C) shows grains with varied shapes, textures, and dimensions, and it is also possible to observe quantities of fine materials, which can cause deviations in the absorption index, cohesion, and workability of the materials. CARDOSO (2010) states that when using recycled aggregates, it is necessary to observe the differences regarding the shape, texture and the mechanical resistance of the particles, with the need to adapt these aggregates for their application.

Figure $4(D)$ reveals LPW grains with irregular shapes, different sizes, and mainly the lack of connection between the particles. In the study carried out by MOLINETTI (2016) on lime production waste, the author verifies particles similar to those found in the present research. ANDRADE (2012) characterized LPW through the SEM and XRD methods, verifying 
asymmetric shapes with formations similar to amorphous ones. He adds in his research that probably, for this reason, the carbonate peaks were not visible in the X-ray diffractograms (XRD) of the dry mixture. However, it cannot be alleged with certainty that there were no microcrystalline forms internal to these amorphous formations. The possible explanation for this fact is that the LPW, being in the open air, is hydrated by rain and air humidity becoming $\mathrm{Ca}(\mathrm{OH})_{2}$, and by the action of the $\mathrm{CO}_{2}$ in the air, it becomes $\mathrm{CaCO}_{3}$. However, the sensitivity of the XRD method (around 5\%) does not allow the identification of these minerals peaks, and there may be many more minerals with crystalline structures (as Calcite, Dolomite, Anquerita) in the material.

\subsection{Axial Compressive Resistance of the Compositions}

Table 3 shows the averages of the axial compressive resistances of the 19 molded compositions, and Figure 5 reveals the resistance increase of compositions 16 and 17 with curing time.

Table 3 - Axial compressive resistance

\begin{tabular}{cccccccccccccc}
\hline \multicolumn{1}{c}{ Compositions, \% } & \multicolumn{1}{c}{ Curing age (days) } \\
\cline { 2 - 5 } & $\mathbf{1 0 T}$ & PPW & CW & LPW & $\mathbf{3}$ & $\mathbf{7}$ & $\mathbf{1 4}$ & $\mathbf{2 8}$ & $\mathbf{6 0}$ & $\mathbf{9 0}$ & $\mathbf{1 8 0}$ & $\mathbf{3 6 5}$ & $\mathbf{7 2 0}$ \\
\hline 1 & 30 & 30 & 25 & 15 & 1,84 & 2,52 & 2,70 & 2,71 & 2,77 & 3,72 & 4,78 & 5,40 & 5,57 \\
2 & 20 & 40 & 25 & 15 & 1,20 & 2,10 & 2,31 & 2,44 & 2,71 & 2,90 & 3,15 & 4,93 & 5,41 \\
3 & 40 & 20 & 25 & 15 & 1,83 & 2,67 & 2,75 & 2,86 & 2,93 & 3,03 & 3,80 & 5,06 & 5,26 \\
4 & 25 & 35 & 25 & 15 & 2,35 & 2,70 & 2,99 & 3,28 & 3,60 & 3,83 & 5,17 & 6,27 & 6,27 \\
5 & 35 & 25 & 25 & 15 & 2,01 & 2,60 & 2,89 & 2,94 & 3,23 & 3,76 & 4,56 & 5,37 & 5,99 \\
6 & 15 & 45 & 25 & 15 & 1,40 & 1,70 & 1,67 & 1,56 & 1,54 & 2,15 & 3,52 & 5,17 & 5,17 \\
7 & 45 & 15 & 25 & 15 & 2,62 & 3,40 & 3,45 & 3,61 & 3,88 & 4,43 & 4,78 & 5,70 & 5,90 \\
8 & 30 & 20 & 30 & 20 & 2,45 & 2,59 & 3,17 & 3,06 & 3,11 & 3,39 & 4,77 & 6,19 & 6,19 \\
9 & 20 & 30 & 30 & 20 & 1,69 & 2,06 & 2,53 & 2,68 & 2,75 & 3,65 & 4,54 & 6,05 & 6,86 \\
10 & 25 & 25 & 30 & 20 & 2,51 & 2,67 & 2,60 & 2,89 & 2,88 & 2,75 & 3,25 & 5,31 & 5,31
\end{tabular}




\begin{tabular}{llllllllllllll}
11 & 10 & 40 & 30 & 20 & 1,33 & 1,56 & 2,00 & 2,77 & 2,92 & 3,10 & 3,79 & 5,09 & 6,11 \\
12 & 40 & 10 & 30 & 20 & 2,84 & 3,93 & 4,00 & 4,41 & 3,64 & 4,82 & 6,59 & 6,85 & 7,06 \\
13 & 30 & 20 & 25 & 25 & 2,66 & 3,12 & 3,86 & 4,06 & 3,80 & 4,97 & 5,13 & 6,56 & 7,15 \\
14 & 20 & 30 & 25 & 25 & 1,95 & 2,26 & 2,76 & 2,94 & 3,72 & 4,08 & 4,38 & 6,05 & 6,05 \\
15 & 25 & 25 & 25 & 25 & 2,99 & 3,60 & 4,31 & 4,55 & 5,35 & 5,56 & 6,08 & 6,52 & 6,82 \\
16 & 10 & 40 & 25 & 25 & 3,00 & 3,34 & 3,75 & 4,07 & 4,32 & 4,79 & 5,87 & 6,97 & 7,91 \\
17 & 40 & 10 & 25 & 25 & 4,94 & 5,75 & 6,58 & 6,92 & 7,61 & 7,72 & 9,63 & 10,47 & 11,47 \\
18 & 35 & 15 & 25 & 25 & 4,17 & 4,50 & 5,10 & 6,10 & 6,38 & 6,58 & 6,99 & 6,85 & 7,15 \\
19 & 15 & 35 & 25 & 25 & 2,86 & 3,08 & 3,11 & 4,05 & 4,24 & 4,45 & 5,58 & 6,02 & 6,38 \\
\hline
\end{tabular}


Figure 5 - Axial compressive resistance of compositions 16 and 17

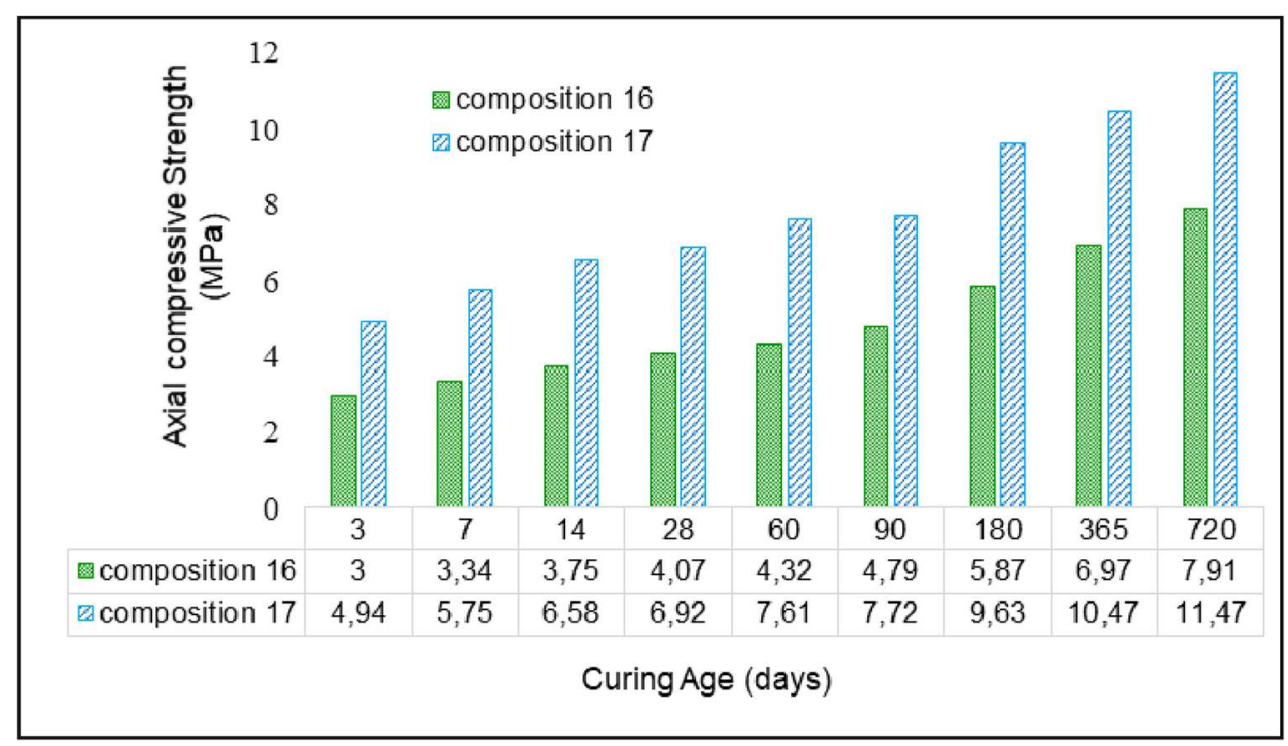

Analyzing the average axial resistances, compositions 16 and 17 stand out (Table 3 and Figure 5), given that the concrete waste (CW) and lime production waste (LPW) percentages (\%) remained the same, changing only the iron ore tailings (IOT) and pulp production waste (PPW) amounts (percentage). There is also a tendency to increase resistance (Table 3) with an increase in IOT content and decrease with a reduction in PPW (pulp production waste) content. Composition 17 stands out concerning the others, as there is a constant gain in resistance over time (age of cure). Comparing the resistances required in Standard NBR 7170 (ABNT, 1983) at 28 days of age, compositions 12, 13, 15, 16, 17, 18, and 19 (07 compositions) fall into Class C, i.e., solid bricks with resistance higher than 4.0 $\mathrm{MPa}$. It is also possible to notice that among the 19 (nineteen) compositions containing lime production waste (LPW), 15 (fifteen) reached resistance of Class $\mathrm{A}$, i.e., above $1.50 \mathrm{MPa}$.

\subsection{Morphological Structure of Compositions 16 and 17}

The morphological structures of composition 16 (proportions, see Table 1) were analyzed using SEM (Scanning Electron Microscopy), shown in Figures 6 and 7. Figure 6 presents 15,000x-magnification images for the curing periods of 3 and 28 days, and Figure 7, 6,000x magnification for the initial curing periods (dry mix), 3, 7, and 28 days. The 
morphological structures of composition 17 (proportions, see Table 1) can be seen in Figure 8, only with a 6,000x magnification, for the initial curing periods, 3, 7, and 28 days.

Figure 6 - Morphological Structure of Composition 16 - 15,000x magnification

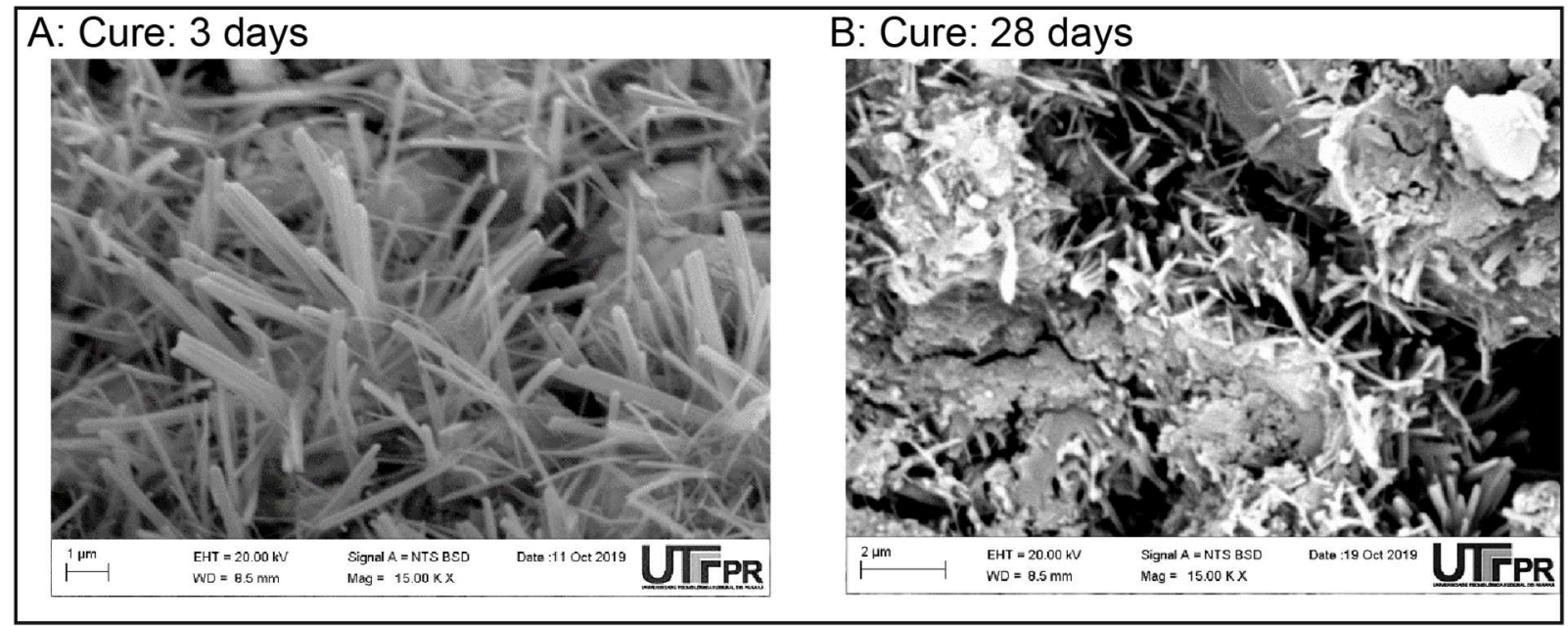

Figure 7 - Morphological Structure of Composition 16 -6,000x magnification
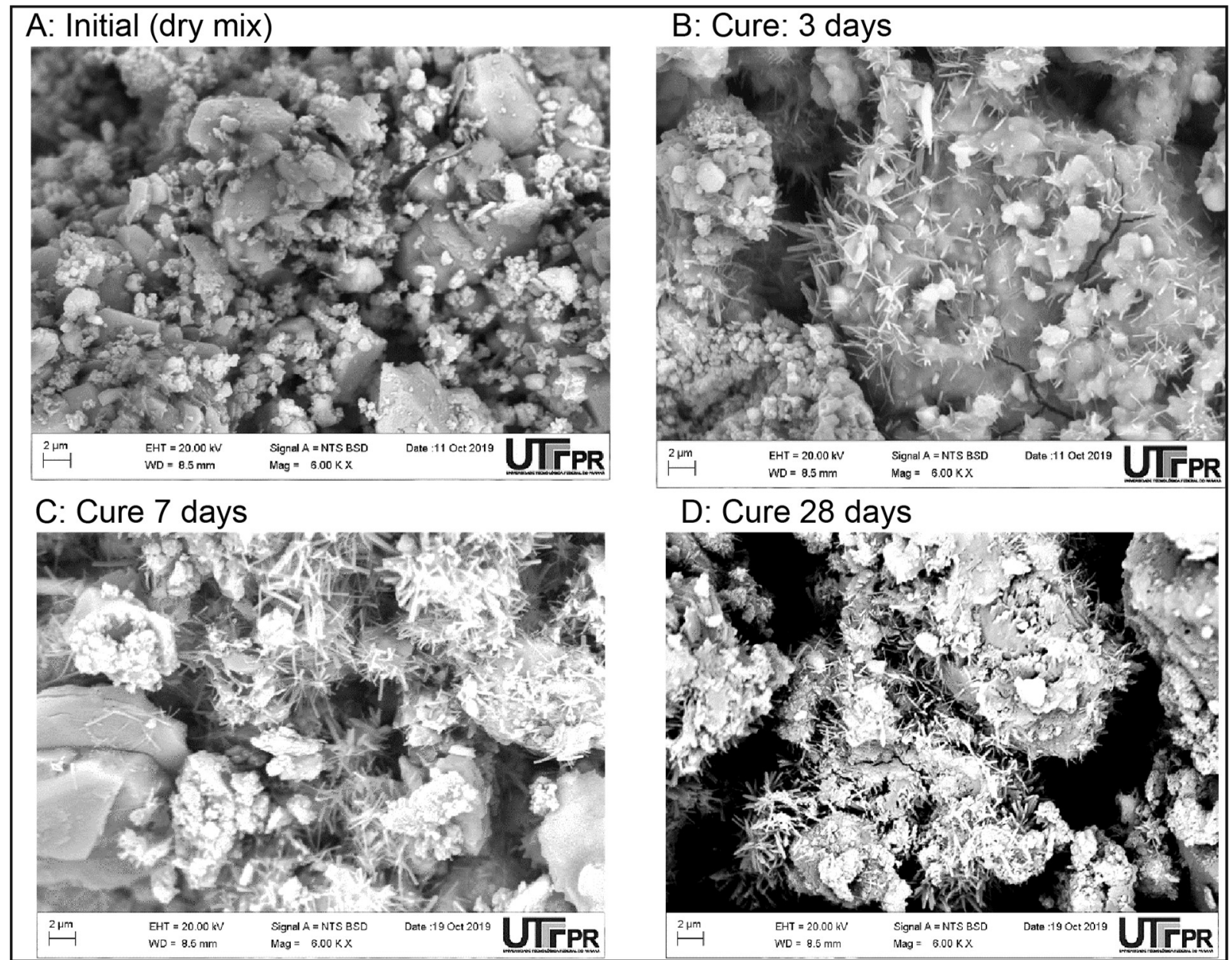

Figure 8 - Morphological Structure of Composition 17 - 6,000x magnification 


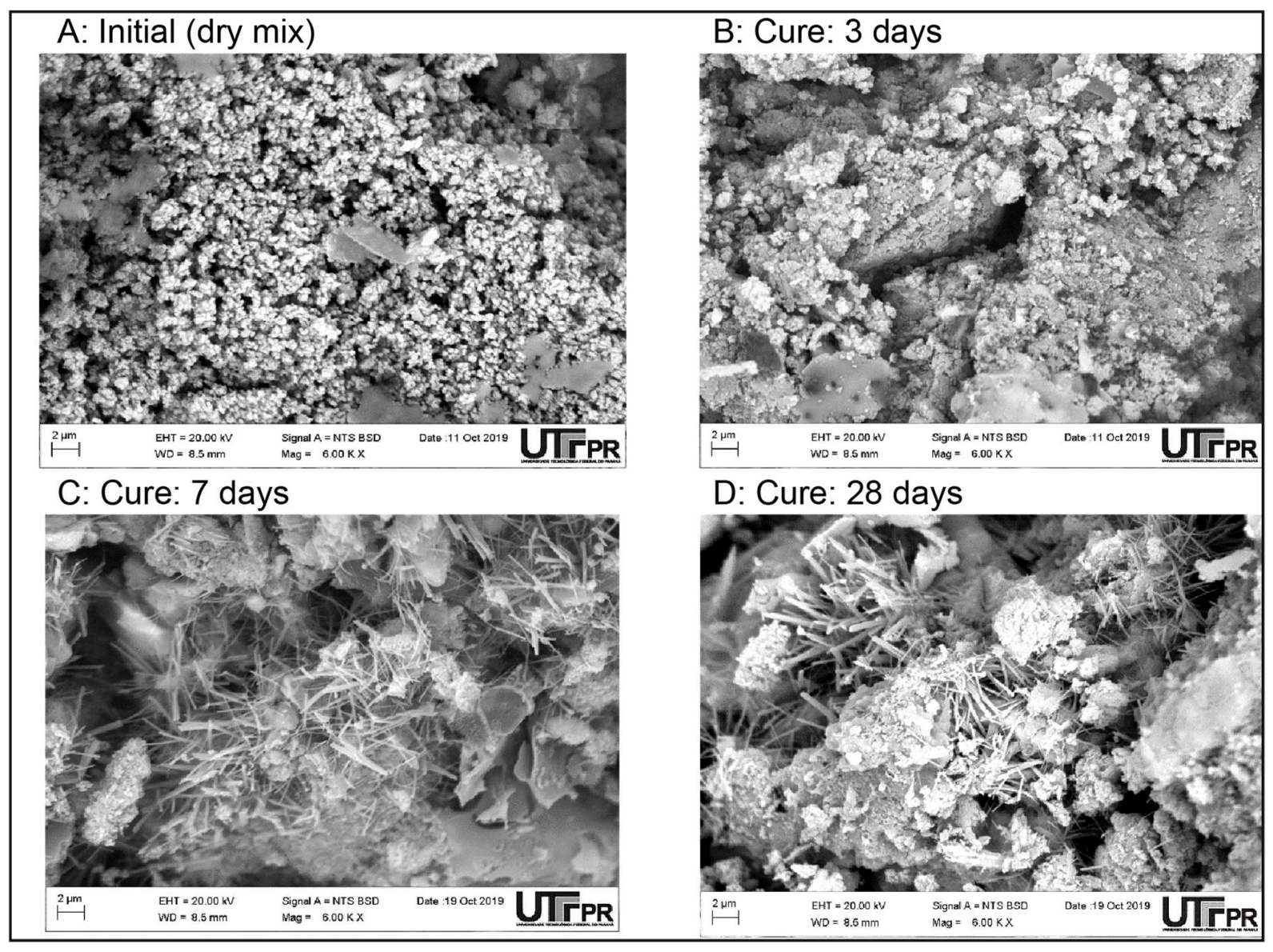

It is plainly seen the formation of ettringite crystals at 3 and 28 curing days in Figure 6 , being its formation reaction one of the factors responsible for the hardening of the binder paste. According to MEHTA (2008), when cement is dispersed in water, the calcium sulfate and the calcium components formed at high temperatures start to come into solution, and the liquid phase quickly becomes saturated with various species of ions, as a result of interaction between calcium, sulfate, aluminate and hydroxyl ions. Within a few minutes of cement hydration, non-circular crystals of hydrated calcium trisulfoaluminate, known as ettringite, begin to appear. In Figure 7, the continuous formation of hydrated calcium silicate (C-S-H) can be seen in the initial ages, 3, 7, and 28 days (6,000x magnification), with nonhomogeneous structures, dense parts, and other porous or empty ones. However, in the porous (void) regions, it is possible to find the individual hydrated phases with higher magnification, for example, the massive crystals of calcium hydroxide, thin and long needles of ettringite and aggregation of small fibrous crystals of hydrated calcium silicate can be seen at 15,000x magnification (Figure 6). The sample preparation technique for obtaining 
images (Figures 6, 7, and 8) using the scanning electron microscope allows drying, so the pores may appear empty.

For MEHTA (2008), in Portland cement-based compounds, depending on the ambient moisture and its porosity, untreated cement paste might retain a large amount of water. Water can exist in the hydrated cement paste in many ways. Thus, there is capillary water, which is water present in voids larger than 50 Angstrom and whose removal may cause the system to retract. Furthermore, there is the adsorbed water, which under forces of attraction, the water molecules are physically adsorbed on the surfaces of solids, and the loss of adsorbed water is responsible for the retraction of the hydrated cement paste. For all these reasons, cement-based composites must have little mixing water and less porosity, avoiding the retraction or swelling of the system by adding water or losing it to the environment. Likewise, Figure 8 indicates structures with the formation of ettringite crystals, which resulted in the best increases in mechanical strength (axial compression) over the curing ages for composites 16 and 17 (Table 3 and Figure 5).

\section{Conclusion}

Only the four types of industrial waste (IOT, PPW, LPW, CW) were used to produce the specimens for tests at the laboratory level. The results showed an increase in resistance with the curing time in the 19 developed compositions. It is also noteworthy that no type of binder was used in the molding of the specimens, such as Portland cement, lime, or plaster, to join or agglomerate the four residues. The samples were just compacted in a manual press applying a force of 10 ton, giving support and resistance to compression to the molded specimens.

Compositions 16 and 17 exhibited the most significant increases in compressive resistance among the developed compositions, and it is clear from the analysis of their morphological structures that there was the formation of ettringite crystals at 3 and 28 days, represented by the non-circular crystals of hydrated calcium trisulfoaluminate. It is also noticed the formation of hydrated calcium silicate (C-S-H) at the ages of 3, 7, and 28 days of cure. Therefore, one of the main advantages of using these residues (IOT, PPW, CW, and 
LPW) is that it was possible to neutralize alkalinity, providing non-hazardous and environmentally correct materials, making their adoption as raw materials an excellent way of reusing them as materials for civil construction.

\section{References}

ABNT. Associação Brasileira de Normas Técnicas. NBR 6453 Cal virgem para construção civil - Requisitos. Rio de Janeiro, 2003.

. NBR 7170 Tijolo maciço cerâmico para alvenaria. Rio de Janeiro, 1983.

. NBR 15270-1 Componentes cerâmicos - blocos e tijolos para alvenaria, parte 1 requisito, 2017 .

ANTT, Agência Nacional de Transportes Terrestres. Recursos de Desenvolvimento Tecnológico RDT: Estudo da viabilidade técnica de utilização de rejeitos de minério de ferro em pavimentos rodoviários. Relatório Final, Nova Lima/MG, 2018.

ANDRADE, CLARICE DE. Materiais para Construção Civil à Base de Cinzas de Madeira, Lodo de ETA e Resíduos da Produção de Cal. Dissertação de Mestrado do PIPE da UTFPR, campus Curitiba, 2012.

BEZERRA, CAROLINA GOULART. Característica do Rejeito de Minério de Ferro (IOT) e Avaliação da sua Influência no Comportamento Físico-Químico e Mecânico de Pasta de Cimento. Dissertação de mestrado apresentada ao Programa de Pós-graduação em Engenharia Civil, COPPE, da Universidade Federal do Rio de Janeiro, 2017.

BRACELPA. Associação Brasileira de Celulose E Papel. Dados do Setor de celulose e papel. Brasília. 2016.

CARDOSO, JOSÉ RIBAMAR DE ABREU. Uso de Agregado de Entulho da Construção Civil de Manaus - AM para obtenção de Blocos de Argamassa Celular. Dissertação de Mestrado no Programa de Pós Graduação em Engenharia Mecânica e de Materiais do Departamento de Pesquisa da UTFPR. Manaus 2010.

CHIU. C.; STROPKY, D. (2014), Advanced Process Simulation and Training, Process Simulations Ltd., Vancouver, www.psl.bc.ca/honeywellprocess.com/library/training.

DEDAVID, BERENICE ANINA; Gomes Carmem Isse; Machado Giovanna. Microscopia Eletrônica de Varredura. Aplicação e preparação de amostras. Editora ediPUCRS, Porto Alegre 2007.

FERREIRA J.M.F.; OLHERO S.M. Al-rich sludge treatments towards recycling. Journal of the European Ceramic Society, v. 22, p. 2243-2249, 2002. 
GARCIA, A. Setor de fabricação de cimento e cal. Inspeção geral do ambiente e do ordenamento do território. Lisboa. 2008.

HANSEN, T. C.; HEDEGARD, S. Properties of recycled aggregate concretes as affected by admixtures in original concretes. ACI Materials Journal, v. 81, n. 1, p. 21-26, 1984.

HANSEN, T. C.; NARUD, H. Strength of recycled concrete made from crushed concrete coarse aggregate. Concrete International, v. 5, n. 1, p. 79-83, 1983.

HANSEN, T.C. Recycled of demolished concrete and mansory. London: Chapman \& Hall, 1992. 316p. Part One: Recycled aggregates and recycled aggregate concrete, p. 1-160. (RILEM TC Report 6).

HEWLETT PETER. Lea's Chemistry of Cemente and Concrete. $4^{\text {a }}$ Edição, London: Arnold Publishers, p.485-500, 1998.

LEBÉIS, V. D. L. Viabilidade do uso do resíduo da fabricação do papel em argamassas. Campinas, 2003. 115p. Dissertação (Mestrado em Engenharia Civil) - Faculdade de Engenharia Civil, Universidade Estadual de Campinas, Campinas, 2003.

LEITE, MONICA B. Avaliação de Propriedades Mecânicas de Concretos Produzidos com Agregados Reciclados de Resíduos de Construção e Demolição. Universidade Federal do Rio Grande do Sul. Escola de Engenharia. Programa de Pós-Graduação em Engenharia Civil, 2001.

MAGALHÃES, LUCIANO FERNANDES. Avaliação do rejeito de minério de ferro como material cimentício suplementar. Dissertação de Mestrado, Programa de Pós-Graduação em Engenharia de Materiais do Centro Federal de Educação Tecnológica de Minas Gerais (Cefet/MG), 2018.

MANSKINEN, K.; NURMESNIEMI, H.; PÖYKIÖ, R. Total and extractable non-process elements in green liquor dregs from the chemical recovery circuit of a semichemical pulp mill, Chem. Eng. J. 166 (2011) 954-961.

METHA, P.K; MONTEIRO, P.J.M. Concreto, Mircroestrutura, Propriedades e Materiais. $3^{a}$ edição. Editora IBRACOM, 2008

MOLINETTI, ANDRÉA. Utilização de Resíduos de Argamassa, lodo de anodização de alumínio e cal para a formação de um novo compósito. Dissertação de Mestrado, PPGEC da UTFPR/campus Curitiba, 2016.

MONTE M.C; FUENTE, E.; BLANCO, A.; NEGRO, C. Waste management from pulp and paper production in the European Union, Waste Manage. (Oxford) 29 (2009) 293-308.

MYMRIN V.; PONTE H. A.; YAMAMOTO C.I. Synthesis of new colloidal formations during the strengthening of different activated hydrated metallurgical slags. Colloids and Surfaces $A$ : Physicochemical and Engineering Aspects, v.220, p.211-221, 2003. 
MYMRIN, V. MOLINETTI, A. ALEKSEEV, K., AVANCI, M. A., KLITZKE, W., SILVA, D. A., FERRAZ, F. A., IAROZINSKI, A. CATAI, R. E. Characterization of construction materials on the base of mortar waste, activated by aluminum anodization sludge and lime production waste, Construction and Building Materials, Volume 212, 2018, p. 202-209.

MYMRIN V., PRESOTTO A. P., ALEKSEEV K., AVANCI M. A, ROLIM P. H.B., PETUKHOV V., TASKIN A. Application of hazardous serpentine rocks' extraction wastes in composites with glass waste and clay-sand mix to produce environmentally clean construction materials Construction and Building Materials 234 (2020) 117319.

SBRIGHI ETO, C. Concreto: Ensino, pesquisa e realizações. Ed. G.C.Isaía. São Paulo: IBRACON, 2005. 2 v. 1600 p.

SCRIVENER, K. L.; JOHN, V. M.; GARTNER, E. M. Eco-efficient cements: Potential economically viable solutions for a low-CO2 cement-based materials industry. Cement and Concrete Research, v. 114, p. 2-26, 2018. DOI: 10.1016/j.cemconres.2018.03.015. 